\title{
Plasma Exchange of Malignant Multiple Sclerosis
}

\author{
K.G. WARREN, P.A. GORDON, T.A. McPHERSON
}

SUMMARY: A 17-year old female with "malignant" multiple sclerosis died 45 weeks after the onset of the disease. Postmortem examination confirmed the clinical diagnosis of multiple sclerosis. After 30 weeks of rapid clinical progression, the patient was treated with two courses of plasma exchange therapy without immunosuppression. This form of therapy caused a drop in cerebrospinal fluid myelin basic protein levels in one instance, but not in another. Controlled clinical trials are required to determine whether plasma exchange therapy is of value in the management of patients with multiple sclerosis, and the monitoring of cerebrospinal fluid myelin basic protein, if elevated, may be one useful marker to follow as part of these studies.

RESUMÉ: Une jeune femme de 17 ans sauffrant de sclérose en plaques "maligne" est morte 45 jours après le début de la maladie. Le diagnostic clinique a été confirmé par l'examen post-mortem. Après 30 semaines de progression clinique rapide, la patiente reçut deux traitements d'échanges plasmatiques sans immunosuppression. Cette forme de thérapie causa une chute des taux de la protéine myélinique basale dans le liquide céphalo-rachidien dans un certain cas mais non dans un autre. Une réponse à cette approche pour la sclérose en plaques nécessitera une étude contrôllée et l'observation de la protéine myélinique basale dans le liquide céphalo-rachidien peut être un facteur utile à suivre dans ces études.

From the Department of Medicine and Laboratory Medicine (Division of Hematology), University of Alberta Hospital, 112 Street and 83 Avenue, Edmonton, Alberta, T6G 2 B 7.

Reprint Requests to: Dr. K.G. Warren, 9-101 Clinical Sciences Building, University of Alberta, Edmonton, Alberta, T6G 2 B 7.

\section{INTRODUCTION}

The "malignant" form of multiple sclerosis (MS) is characterized by severe relapses which may be fatal within a few months or years. About one patient in every 20 dies within five years from the onset of the disease (McAlpine et al., 1972). Factors responsible for the clinical variability of MS are unknown.

Recent attempts at modifying the disease process in MS patients have included not only immunosuppression (Mertin et al., 1980) and transfer factor (Basten et al., 1980), but also plasma exchange therapy. Dau et al. (1980) observed modest improvement of neurologic function in 7 of 8 patients with progressive MS subjected to longterm plasmapheresis in combination with azathioprine and pulsed prednisone therapy. Weiner and Dawson (1980) observed moderate but unequivocal improvement in 6 of 8 patients with chronic progressive MS after short-term plasmapheresis, prednisone, and azathioprine therapy. In 4 patients, improvement gradually disappeared in the two to three months after therapy, and 2 patients remained improved. Three additional patients in acute severe exacerbations refractory to steroid therapy, showed substantial recovery commencing with plasmapheresis. Plasma exchange therapy in MS patients has not yet been evaluated by controlled clinical trials with shamexchanges.

We report here a 17 -year old female patient with malignant MS who died within one year of the onset of the disease, and who was treated by plasma exchange therapy.

\section{CASE REPORT}

In August, 1980, a 17-year old girl suddenly lost vision in her right eye and over the next two weeks developed numbness of her left arm and leg. These symptoms fluctuated but persisted until November, 1980, when she developed bilateral visual loss and numbness as well as nausea, vertigo and profound loss of hearing in both ears. Asymmetrical weakness, worse on the right side, as well as urinary retention, developed quickly.

When she was re-examined in December, 1980, she was euphoric. Visual acuity was approximately $20 / 100$ in the right eye, and reduced to counting fingers in the left eye. Pupils reacted sluggishly to light. Optic nerve heads showed temporal pallor. Nystagmus was of high amplitude and conjugate on gaze to the left, and of moderate amplitude and conjugate on gaze to the right. Both upward and downward vertical nystagmus was present. Hearing loss was profound in the left ear and reduced in the right ear so that whispered voice or a watch tick could not be heard. Ataxia was present in both upper limbs, worse in the left arm. Asymmetrical quadraparesis was present, worse on the right side, and was associated with bilateral increased deep tendon reflexes, clonus, absent abdominal reflexes and extensor plantar responses. Vibration sense was reduced in the hands and feet. Cerebrospinal fluid (CSF) contained 38 mononuclear cells, protein $95 \mathrm{mg} / \mathrm{dl}$ with $18 \%$ gamma globulin which showed oligoclonal banding, and $50 \mathrm{ng} / \mathrm{ml}$ myelin basic protein (MBP). The CSF-MBP levels were determined by a modification of a previously reported silica gel radioimmunoassay (Hsiung et al., 1978). Levels above $8 \mathrm{ng} / \mathrm{ml}$ are considered elevated, and levels above $50 \mathrm{ng} / \mathrm{ml}$ are indicative of marked acute demyelination. The patient was treated with ACTH $60 \mathrm{U} /$ day for 10 days from December 2, 1980. On December 16, 1980, partial remission had developed with improvement of hearing, better vision in the left eye, increased strength in her arms and legs and less dysarthria. Repeat CSF assessment showed 27 mononuclear cells, protein $69 \mathrm{mg} / \mathrm{dl}$ with $16 \%$ gamma globulin with oligoclonal banding and $100 \mathrm{ng} / \mathrm{ml}$ MBP. She remained stable for two to 
three weeks but then began to deteriorate rapidly. Six weeks later her vision had deteriorated so that she could not count fingers and severe dysarthria and dysphagia had developed. Eyes were deviated to the right and she was not able to look to the left side. Legs were paralyzed, and arm strength had further deteriorated. Sensation for vibration, proprioception, touch and pinprick was absent over the legs and perineum and reduced over the trunk and hands. The third CSF assessment done when she was in acute relapse showed 1 mononuclear cell, protein 88 $\mathrm{mg} / \mathrm{dl}$ with $16 \%$ gamma globulin illustrating oligoclonal banding and 75 $\mathrm{ng} / \mathrm{ml}$ MBP. Despite a second course of ACTH therapy, she continued to deteriorate so that by February 13, 1981 , she was in a locked-in syndrome. She was able to blink her eyelids to command, but was unable to move the eyes vertically or horizontally. Facial diplegia was present and the jaw was tightly closed in spasm. Complete loss of control of swallowing and respirations necessitated respirator care. Arms and legs were completely paralyzed, and there was no visible response to pain. Periodic myoclonic movement occurred in the right arm. At this time the fourth CSF assessment showed 6 mononuclear cells, protein $42 \mathrm{mg} / \mathrm{dl}$ with $18 \%$ gamma globulin continuing to show oligoclonal banding and the
MBP level remained high at $64 \mathrm{ng} / \mathrm{ml}$.

Plasma exchange was commenced with a Hemonetics Model 30 cell separator. Vessel access was through the ante-cubital veins and 2.0-2.5 litres of plasma was exchanged on each occasion. Plasma was replaced by saline and $25 \%$ salt-poor albumin (Connaught Labs). Six plasma exchanges were carried out within a three-week period. CSF analysis was performed after three exchanges to monitor the effect of plasma exchange therapy. There were no mononuclear cells, protein remained high at $62 \mathrm{mg} / \mathrm{dl}$ with $17 \%$ gamma globulin, but the MBP level had dropped to $13 \mathrm{ng} / \mathrm{ml}$, suggesting removal of MBP by plasma exchanges in the absence of continuing transfer of MBP into CSF due to acute demyelination. Following the completion of the sixth exchange, the CSF showed 1 mononuclear cell, protein $94 \mathrm{mg} / \mathrm{dl}$, with $15 \%$ gamma globulin and MBP level remained low at $14 \mathrm{ng} / \mathrm{ml}$.

Over the next few weeks she improved slightly. Respirator support was discontinued, and she was able to cough and take sips of water. She could look upwards, but not horizontally, and vision remained severely impaired. She was able to flex the left elbow and fingers of the left hand and the left foot could be voluntarily moved. Four weeks after the sixth plasma exchange, the CSF showed 1 mononuclear cell, protein $67 \mathrm{mg} / \mathrm{dl}$ with $20 \%$ gamma globulin and MBP level had again increased to $80 \mathrm{ng} / \mathrm{ml}$. Although she had remained clinically stable with residual severe neurologic impairment, a second course of plasma exchanges was performed in order to determine whether this form of therapy would again result in lower CSF-MBP levels. However, prior to this plasma exchange course, which was 19 days after the last estimation of MBP, the CSF-MBP level had dropped to $15 \mathrm{ng} / \mathrm{ml}$. Following three plasma exchanges the cerebrospinal fluid assessment showed 17 mononuclear cells, protein $62 \mathrm{mg} / \mathrm{dl}$ with $23 \%$ gamma globulin and elevation of MBP to $44 \mathrm{ng} / \mathrm{ml}$.

Subsequently, the patient developed increasing respiratory difficulties, and deceased on May 25, 1981. Postmortem examination of the brain, spinal cord, and optic nerves confirmed the presence of MS. She died 45 weeks after the onset of malignant demyelinating disease.

When each CSF assessment was performed, an aliquot from 8 of 9 studies was stored at $-70^{\circ} \mathrm{C}$. These stored CSF specimens were assayed together to provide a second determination of MBP levels. The specimens were assayed under "blind control." The levels of MBP in CSF as determined by the first and second readings are shown in Table 1.

TABLE 1

Cerebrospinal Fluid Values Before and After Plasma Exchange Therapy

\begin{tabular}{|c|c|c|c|c|c|c|}
\hline \multirow[b]{2}{*}{ Date } & \multirow[b]{2}{*}{ Specimen } & \multirow[b]{2}{*}{$\begin{array}{l}\text { Cell } \\
\text { count }\end{array}$} & \multirow[b]{2}{*}{$\begin{array}{l}\text { Protein } \\
\text { mg/dl }\end{array}$} & \multirow[b]{2}{*}{$\underset{\%}{\text { Gamma globulin }}$} & \multicolumn{2}{|c|}{ Myelin basic protein $(\mathrm{ng} / \mathrm{ml})$} \\
\hline & & & & & $\begin{array}{l}\text { Initial } \\
\text { report }\end{array}$ & $\begin{array}{l}\text { Second } \\
\text { report }\end{array}$ \\
\hline 12.1 .80 & Initial CSF assessment & 38 & 95 & 18 & 50 & 60 \\
\hline 12.17 .80 & $\begin{array}{l}\text { After } 60 \text { U ACTH IV daily } \\
\text { for } 10 \text { days }\end{array}$ & 27 & 69 & 16 & 100 & - \\
\hline 1.26 .81 & Before second ACTH course & 1 & 88 & 16 & 75 & 65 \\
\hline 2.16 .81 & Pre-first plasma exchange & 6 & 42 & 18 & 64 & 55 \\
\hline 2.27 .81 & After 3 plasma exchanges & 0 & 62 & 17 & 13 & 21 \\
\hline 3.9 .81 & After 6 plasma exchanges & 1 & 94 & 15 & 14 & 16 \\
\hline 4.8 .81 & 4 weeks post-exchange & 1 & 67 & 20 & 80 & 26 \\
\hline 4.27 .81 & Pre-second plasma exchange & 0 & 55 & 20 & 15 & 30 \\
\hline 5.7 .81 & After 3 plasma exchanges & 17 & 62 & 23 & 44 & 35 \\
\hline
\end{tabular}

-Initial determination of CSF-MBP levels done before freezing at varying times up to several hours after each lumbar puncture.

*"Repeat determination of all CSF specimens which were collected and stored at $-70^{\circ} \mathrm{C}$. 


\section{RESULTS AND DISCUSSION}

Although preliminary observations suggest a possible role for plasma exchange in MS, the lack of controlled studies has resulted in considerable uncertainties in many areas. These include the mechanism of action of plasma exchange, patient selection in a variable, unpredictable disease of different subtypes, objectivity of clinical assessments, placebo effect, concomitant drug therapy, intensity of plasma exchange and laboratory methodology and interpretation.

This patient with "malignant" MS was treated by plasma exchange therapy without immunosuppression. There was no immediate improvement in neurological status although the patient clinically stabilized and respiratory support was discontinued. CSF values before, during and after the first series of plasma exchanges, on samples studied shortly after the sample was obtained, showed little change in IgG levels, but there appeared to be a fall in MBP levels, suggesting a cause-and-effect relationship. When CSF-MBP levels rose four weeks later to $80 \mathrm{ng} / \mathrm{ml}$, a second series of exchanges was considered warranted and performed 19 days later. However, the immediate pre-exchange MBP level was again reduced to $15 \mathrm{ng} / \mathrm{ml}$ and then increased to $44 \mathrm{ng} / \mathrm{ml}$ in a sample taken after three plasma exchanges. In retrospect, the sample showing a value of $80 \mathrm{ng} / \mathrm{ml}$ appeared discordant with the clinical impression of relatively stable disease following the first series . of plasma exchanges. Accordingly, a repeat run of the 8 of 9 CSF samples which had been kept frozen at $-70^{\circ} \mathrm{C}$ was performed as a batch. Results from this run confirmed our suspicion that the value of $80 \mathrm{ng} / \mathrm{ml}$ was the most discordant. Previous results from our laboratory indicate the following with respect to quality control relating to the silica gel assay for MBP (Hsiung et al., 1978): Intra-assay variability on 20 identical samples run as a batch was $21.75 \pm 2.02$ (s.d.) $\mathrm{ng} / \mathrm{ml}$, coefficient of variation, $9.27 \%$; inter-assay variability, using aliquots from the same pool which were frozen and separately thawed immediately before being assayed, done in duplicate on 20 different occasions, was $23.6 \pm 2.4$ (s.d.) $\mathrm{ng} / \mathrm{ml}$ with a coefficient of variation of $10.1 \%$; and effect of repeated freeze-thawing on samples assayed in duplicate fresh and up to a total of 6 freeze-thaws over seven runs was 24.6 \pm 2.07 (s.d.) $\mathrm{ng} / \mathrm{ml}$ with a coefficient of variation of $8.4 \%$ (the actual mean values in $\mathrm{ng} / \mathrm{ml}$ for the seven runs were 22 (pre-freeze), and 23, 23, 24, 26, 27 , 27 for samples freeze-thawed from 1-6 times respectively. These results were done under well controlled circumstances on different pools of CSF showing a value of less than $4 \mathrm{ng} / \mathrm{ml}$ of MBP before being "spiked" with a known amount of MBP. The difference seen between the initial test and the second test, which is higher than would be expected from our quality control studies, is likely to be due to the variable time interval between the taking of the sample and its being tested without freezing. Nevertheless, the only value which appears particularly discordant is the value of $80 \mathrm{ng} / \mathrm{ml}$. If this value is disregarded, then it seems reasonable to suggest that plasma exchange can cause a detectable, substantial fall in CSF-MBP levels, and may be a useful marker for monitoring one of the effects of plasma exchange in patients with MS who have elevated levels of CSF-MBP. This is the only report to date of repeated determinations of CSF-MBP in one individual treated by plasma exchange therapy. If CSF-MBP levels are acceptable as a measure of active demyelination (Whitaker et al., 1980) further studies are required to determine the effect; if any, of plasma exchange therapy on these levels.

This case illustrates many of the difficulties in assessing the potential value of plasma exchange in MS. The intensity of plasma exchanges given (40 $\mathrm{ml} / \mathrm{kg}$ ) was less than previous reports (50 mg/kg - Dau et al., 1980; $60 \mathrm{mg} / \mathrm{kg}$ - Weiner and Dawson, 1980) and fewer exchanges were performed. However, this volume of plasma exchange has previously been shown to be sufficient to significantly reduce levels of $\mathrm{IgG}, \mathrm{C} 3$ and $\mathrm{C} 4$ and circulating immune complexes in other diseases (Rothwell et al., 1980), and a 2 to 3 litre plasma exchange in an individual with plasma volume of 3 litres appears reasonable in terms of efficiency of removal of in- travascular components (Jones et al., 1981). Concomitant immunosuppression with prednisone and azathioprine may be an essential component of the plasma exchange program and was not given to this patient at the time of exchange. Prior to plasma exchange therapy, the patient had temporarily improved with ACTH therapy. However, it was believed that immunosuppression would obscure interpretation of plasma exchange effect on CSF immunochemical values of MBP. Consideration of the first series of CSF results suggests spontaneous fluctuations in MBP levels occur in acute "malignant" MS, but attention to the second series of CSF results suggests that plasma exchange therapy reduces active demyelination and CSFMBP levels. The level of CSF-MBP recorded may be influenced by two factors: the activity level of the demyelinating process, and by plasma exchange therapy. The fall in CSF-IgG levels previously reported in plasmaexchanged patients may be in part related to the immunosuppression given (Elsner, 1978).

Patients with the unremitting or malignant forms of the disease are unlikely to respond to this form of therapy, and long-standing deficits are unlikely to be reversed. Double blind clinical trials comparing the effect of plasma exchange versus sham exchange on MS patients in various stages of disease are required. Such trials are now in progress. This case illustrates the caution required in interpretation of changes in laboratory values during plasma exchange in this disease of unknown etiology.

ACKNOWLEDGEMENTS

The technical assistance of Mrs. L. Marsh, R.N., Ms. V. Jeffrey, Ms. S. Sunderland, M.Sc., and Ms. I. Catz, M.Sc., was appreciated. We wish to thank Ms. D. Cummins and Dr. D. Carroll for assistance in the care of this patient, and Dr. H. Jacobs for performing independent neurological assessments before and after the plasma exchanges. This research was supported by the Multiple Sclerosis Society of Canada, and by Friends of Multiple Sclerosis Research in Edmonton, Alberta.

\section{REFERENCES}

BASTEN, A., POLLARD, J.O., STEWART, G.J., FRITH, J.A., McLEOD, J.G., WALSH, J.C., GARRICK, R., and VAN DER BRINK, C.M. (1980). Transfer factor in treatment of MS. Lancet, 2, 931-934. 
DAU, P.C., PETAJAN, J.H., JOHNSON, K.P., PANITCH, J.S., and BORNSTEIN, M.B. (1980). Plasmapheresis in multiple sclerosis: Preliminary findings. Neurology, $30,1023-1028$.

ELSNER, W., TOURTELLOTTE, W.W., MURTHY, K.M., MA, B.I., POTVIN, A.R., and SYNDULKO, K. (1978). Multiple Sclerosis: Effect of dexamethasone on in situ central nervous system IgG synthesis. Neurology, 28, 403-404.

HSIUNG, H.M., WU, J., and McPHERSON, T.A. (1978). Silica gel radioimmunoassay for myelin basic protein. Clin. Biochem., 11 , 54-56.
JONES, J.V., CLOUGH, J.D., and KLIMENBERG, J.R. (1981). The role of therapeutic plasmapheresis in the rheumatic diseases. J. Lab. Clin. Med., 97, 589-598.

McALPINE, D., LUMSDEN, C.E., and ACHESON, E.D. (1972). Multiple Sclerosis: A Reappraisal, 2nd edition, p. 217. Churchill Livingstone, London.

MERTIN, J., KNIGHT, S.C., RUDGE, P., THOMPSON, E.J., HEALY, M.J.R. (1980). Double blind controlled trial of immunosuppression in the treatment of M.S. Lancet 2,941-951.
ROTHWELL, R.S., DAVIS, P., GORDON, P.A., DASGUPTA, M.K., JOHNY, K.V., RUSSELL, A.S., and PERCY, J.S. (1980). A controlled study of plasma exchange in the treatment of severe rheumatoid arthritis. Arthritis Rheum., 23, 785-790.

WEINER, H.L., and DAWSON, D.M. (1980). Plasmapheresis in multiple sclerosis: Preliminary study. Neurology, 30, 1029 . 1033.

WHITAKER, J.N., LISAK, R.P., BUSHER, B.M., FITCH, O.H., SEYER, J.M., KRANCE, R., LAWRENCE, J.A., CHIEN, L.T., and O'SULLIVAN, $P$. (1980). Immunoreactive myelin basic protein in the cerebrospinal fluid in neurological disorders. Annals Neurol., 7, 58-64. 